\title{
Blanche the aesthete: a kierkegaardan reading of a streetcar named desire
}

\author{
Kamal Abbasi* \\ English Language and Literature, Razi University, Kermanshah Iran \\ *E-mail address: kmal_1986@yahoo.com
}

\begin{abstract}
Tennessee Williams, the modern American dramatist, had his own unique school of dramaturgy. The dramas which he depicted are populated by characters who are lonely, desperate, anxious, alienated, and in one word lost. They face challenges which they may overcome or not, through the choices they make. All these moods and conditions are clearly seen and explained in the theory of existentialism, so Williams' inspiration from the philosophy is seen. Most existential theorists provide fertile ground to cultivate Williams' works on. Kierkegaard, as the so-called founder of the philosophy, has a theory which is quite applied to Williams' dramaturgy that is telling on the life and mentality of the characters in his plays. In his theory Kierkegaard enumerates three levels of existence which are characterized by their own features and mentality: they are respectively: aesthetic, ethical, and religious. The aesthetic is characterized by the pain and pleasure of the moment, that is, the aesthete follows just his/her instincts and desires. The next stage in Kierkegaard's terminology is the ethical which is characterized by rules, laws, and obligations. The last, but not the least, is the religious stage, however religious not in the conventional and common sense. In Kierkegaard's terminology religious is closest in meaning to individual. To Kierkegaard, the most authentic character is one who has achieved religiosity; otherwise, he or she may suffer from alienation. The aim of this study is to show how Blanche, the main character in Williams' A Streetcar Named Desire (1974), is essentially an aesthete throughout the paly and how being and staying an aesthete leads to her alienation and destruction.
\end{abstract}

Keywords: existentialism; aesthetic; desire; destruction

\section{INTRODUCTION}

Tennessee Williams, being fragile and unable to face a hostile world, seems to be essentially a product of his own time and a social dramatist. Maybe more than any other American dramatist, one can see in Williams' plays strong streaks of personal life and experiences. All throughout his life, he came to fail in an uncompromising world, and more excruciating than all he was misunderstood, especially in the light of his gender and identity. Based on the reflection of all these in Williams' works, the critic Londre believes that in Williams' plays, there is "a focus on characters who are physically wounded or otherwise marginalized by mainstream society; characters seeking lost purity, or escape from the ravages of time, or refuge from the harshness of an uncompromising world, or simple human contact" (46), all emerging from the very nature of Williams' own life. 
Mostly Williams' work is one of alienation and isolation, and when faced with an alien world, as in the case William's characters, the result is isolation, and as it goes isolation is the fundamental theme of the philosophy of existentialism. Existentialism's impact on literature, and especially drama, has been undeniable. It fashioned the mentality of the works of many modern writers, Williams no exception, and helped them best to explain the world created within their works. Mostly it sees man as an isolated creature, who being cast into an exotic world, feels lonely and desperate, and even comes to an estrangement with his own very self. In short existentialism concerns the troubled self, and as Max Scheler believes: "we are the first generation in which man has become fully and thoroughly problematic to himself; in which he no longer knows what he essentially is, but at the same time also knows that he does not know"(qtd in Harper 3).

And the concept of this troubled self has come to light in Kierkegaard's theory of existence very clearly. Kierkegaard's realistic and naturalistic outlook toward existence, however, is characterized by concreteness and practice. To Kierkegaard existence was more genuine and concrete than to be explained theoretically or methodically, as Barret explains "existence and a theory about existence are not one and the same, any more than a printed menu is as effective a form of nourishment as an actual meal" (158). Nonetheless Kierkegaard tries to conceptualize the process of existence

\subsection{The Aesthetic}

The child seems to be the best example of the aesthete, for the child lives solely in the pleasure or pain of the moment. As one critic explains in this stage the emphasis is on man's immediacy and instinct, with no reflection. The aesthete may be full of potentialities, but at the end he chooses to live solely for the pleasurable moments (Broudy, 294). What distinguishes the Aesthetiker's outlook is a dread of boredom, because life teems with vicissitudes which don't guarantee an all-enjoying life for anybody.

Despair, as the key term in Kierkegaard's terminology, is the unavoidable fate in stock for the aesthete. To Kierkegaard as explicated by Barret:

Despair is the extreme emotion in which we seek to escape from ourselves, and it is precisely this latter aspect of despair that makes it such a powerful revelation of what it means to exist as a human individual. We are all in despair, consciously or unconsciously, according to Kierkegaard, and every means we have of coping with this despair, short of religion, is either unsuccessful or demonical. (169)

This excerpt best explains how a typical aesthete comes to identity crisis or alienation in existential terms. What is meant by religion is that code of ethics centered on individuality crystallized through choice and decision which is seen in the later stages.

\subsection{The Ethical}

In Kierkegaardan terms on man's path of complication and development, after the aesthetic stage, there is the ethical stage. It is one of universals and norms, the stage "thou shall and thou shall not". As Barret explains "An ethical rule expresses itself as a universal: all men under such-and such circumstances ought to do such and such" (166). If one is overwhelmed by a system of rules and laws, he is to be lost and get alienated. Indeed there is no universal rule that can contain all individuals with their unique characteristics. So the 
ethical is also not a good label to hold on to, because it does not contain the essence of man, i.e. his individuality.

\subsection{The Religious}

This stage is characterized by choice as the distinguishing element of individuality, i.e. through choice one can achieve that sense of selfhood and authenticity. As Macquarrie explains:

The existent is on his way as the unique person that he is. Either he is himself, he is existing as the unique existent, standing out from the world of objects and going out from any given state of himself or he is being absorbed into the world of objects as just another object, he decides nothing for himself but everything is decided for him by external factors. (74-5)

It is seen that existentialism is a practical school of thought which shows how to be a real and genuine human, and under this philosophy, Kierkegaard's theory of existence and its modes are quite interesting and telling when taking into account man and his life.

\section{BLANCHE THE AESTHETE}

The thirty-two-cent United States postage stamp portraying Williams in white linen against a twilight sky with a streetcar in the background, testifies to the centrality of $A$ Streetcar Named Desire in William's dramatic canon as well as in the American cultural ambience. As to the importance of this work in Williams' own dramatic canon, Londre has it that, "Whether or not A Streetcar Named Desire is Tennessee Williams' 'best' play, or even his most performed play, it is probably the one most closely identified with the dramatist, and it is certainly the one that has elicited the most critical commentary" (45).

Blanche's portrayal, as depicted by Tennessee Williams in A Streetcar, can be given new lights through existentialism and in the light of Kierkegaard's theory of existence; because, as in the words of Londre, she is a character "seeking lost purity or escape from the ravages of time, or refuge from the harshness of an uncomprehending world, or simple human contact". (47)

From the time we see Blanche in the play she is an aesthete escaping the harshness and ravages of time and place through her tricks. At times she reverts to sex with strangers or whoever crops up, at times she goes deep into phantasmagoria engaged with her illusions, and at times she reverts to hot tubs to ease the pain of life. As is seen these are all the characteristics of an aesthete who to escape the pain gets involved with momentary pleasures. However it is important to note why Blanche has come to be an aesthete. Up to then when she first appears in the play, Blanche has been obsessed with loss, loss of many things. Even this obsession and image of loss strikes one from the very beginning in Eunice's inquiry: "What's the matter, honey? Are you lost?' (A Streetcar 11). She has lost her family and all their property, she has lost her beloved because he was a homosexual; and she is left alone. It seems Blanche character and mentality are challenged dramatically and all these conditions necessitate that Blanche should take more serious action, i.e. become the religious person who is beyond any human and normal limit.

However Blanche fails to answer the call of the religious and she becomes an aesthete, one with just instincts and urges such as Blanche becomes when she decides to live solely for 
the pleasurable moments. Also critic Bloom believes that Blanche may at first seem a Whitmaninan, confirms her to be an essential aesthete:

It must seem curious, at first, to regard Blanche DuBois as a failed Whitmanian, but essentially that is her aesthetic identity. Confronted by the revelation of her young husband's preference for an older man over herself, Blanche falls downwards and outwards into nymphomania, phantasmagorichopes, pseudoimaginative collages of memory and desire. (10-110)

On her path of illusion and desire sex acts as a strong motif for her, as critic Normand Berlin explains:

Sex is the play's great leveller. The genteel Blanche and the raw

Stanley ride the same streetcar, but for different reasons. Blanche goes

to her sexual affairs to relieve the broken quality of her life, looking

for closeness, perhaps kindness, in that physical way. She cannot see

herself as a whore because sexual activity was for her a temporary

means for needed affection, the only refuge for her lonely soul. (70)

It is interesting to note that the irony of the play is embedded within this motif of sex or desire; i.e. when she is raped by Stanley what used to be her balm and sedative, at the end, backfires and leads to her alienation and destruction.

Blanche in A Streetcar and in the role of an aesthete is closest to that repetitious image in Williams' works, i.e. the image of the moth. Like the moth that is attracted to a flame that will ultimately destroy it, so too is the moth lady. The critic Falk, too, picks up on the moth image when she discusses the opening scene of $A$ Streetcar. She says that Blanche is dressed all in white and is as delicate as a moth (54). Blanche as a delicate and fragile creature is destroyed by a world that neither understands nor accepts her.

\section{CONCLUSION}

In A Streetcar Named Desire Blanche is seen as an aesthete who through her own means tries to escape the reality of her absurd situation, but as with all aesthetes she has to come to her doomed fate. Blanche should have broken with the aesthetic stage in order to achieve salvation, but she chooses the option of aestheticism, that is the most facile and easy way to just escape the pain and anxiety of life.

She reverts to various means such as sex, phantasmagoria and hot tubs, but none serve to calm her down deeply. She is placed in a hostile world with which she cannot deal as an aesthete, and at last she is raped physically and destroyed mentally.

\section{References}

[1] Barret, William. Irrational Man. Garden City, New York: Doubleday, 1962.

[2] Berlin, Normand. "On Desire and the Character Diaelctic". Ed. Harold

[3] Bloom, Philadelphia: Chelsea House Publishers: 2005.

[4] Bloom, Harold. A Streetcar Named Desire. Philadelphia: Chelsea House Publishers: 2005. 
[5] Broudy, S.Harry. "Kierkegaard's Levels of Existence". Philosophy and Phenomenological Research, Vol1, No.3, 1961, pp. 249-312.

[6] Harper, Ralph. Existentialism. US: Harvard University Press, 1948.

[7] Londre, Elican Haridson. "A streetcar running fifty years". The Cambridge

[8] Companion to Tennessee Williams. Ed. Roudane Matthew C. Cambridge University Press, 1997. Pp: 45-66.

[9] Macquarrie, John. Existentialism. New York: Penguin Books, 1982.

[10] Williams, Tennessee. A Streetcar Named Desire. New York: New Directions, 2004. 